\title{
KONSEP HAK UNTUK DILUPAKAN SEBAGAI PEMENUHAN HAK KORBAN REVENGE PORN BERDASARKAN PASAL 26 UNDANG-UNDANG INFORMASI DAN TRANSAKSI ELEKTRONIK*
}

\author{
Hwian Christianto**
}

Laboratorium Hukum Pidana, Fakultas Hukum, Universitas Surabaya

Jalan Tenggilis Mejoyo, Kali Rungkut, Kecamatan Rungkut, Kota Surabaya, Jawa Timur, 60293

\begin{abstract}
Revenge porn victims experience prolonged and severe mental suffering due to defamation and negative stigma. Article 26.1 of Information and Electronic Transaction Act arranged a mechanism that victims shall request to the internet service provider to block or eliminate an information or content through a court decision. Juridical-normative research method was used through laws and regulations understandings related to victims' rights complemented with understanding the form of victims as predisposed victims and participating victims. As a result, the right to be forgotten is a part of human rights as recognition of oneself as a victim, so that the elimination of violating electronic information that is detrimental to the victim becomes the fulfillment mechanism.
\end{abstract}

Keywords: revenge porn, victim, right to be forgotten, legal procedure.

\section{Intisari}

Korban revenge porn mengalami penderitaan mental yang berkepanjangan dan berat akibat pencemaran nama baik dan stigma negatif. Pasal 26 ayat (1) Undang-Undang Informasi dan Transaksi Elektronik mengatur mekanisme korban harus memohon kepada penyedia jasa internet untuk memblokir atau menghapus informasi melalui penetapan pengadilan. Metode penelitian yuridis normatif digunakan melalui pemahaman peraturan perundang-undangan terkait hak korban dilengkapi pemahaman bentuk korban sebagai predisposed victims dan participating victims. Hasilnya, hak untuk dilupakan merupakan bagian dari hak asasi manusia sebagai pengakuan diri sebagai korban sehingga penghapusan informasi elektronik yang melanggar yang merugikan korban menjadi mekanisme pemenuhanya.

Kata Kunci: hak untuk dilupakan, korban, revenge porn.

\section{Pokok Muatan}

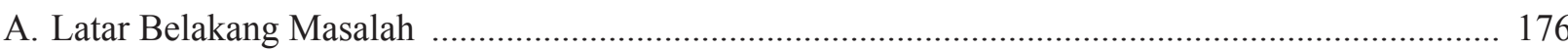

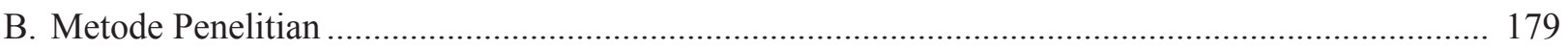

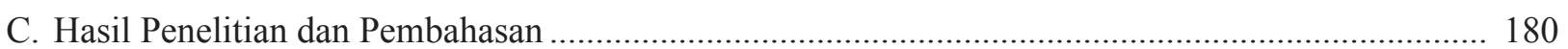

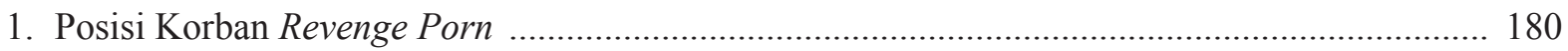

2. Konsep Hak untuk Dilupakan (Right to be Forgotten)................................................................. 183

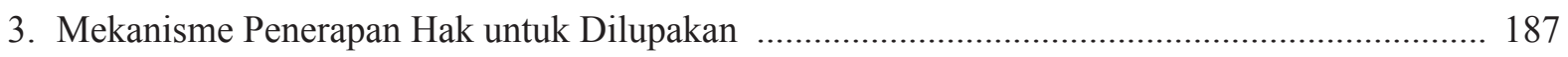

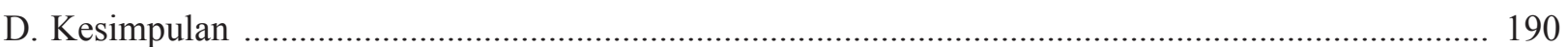

Hasil penelitian yang didanai secara mandiri pada tahun 2020. Penelitian dilaksanakan untuk mengikuti call for paper Jurnal Mimbar Hukum. Alamat korespondensi: hwall4jc@gmail.com atau hwall4jc@yahoo.co.id. 


\section{A. Latar Belakang Masalah}

Penggunaan media internet pada masa sekarang merupakan hal yang sangat penting bagi pemenuhan kebutuhan. Pengguna internet di Indonesia per tahun 2017 telah mencapai angka 143,26 juta jiwa $(54,68 \%)$ dari total penduduk Indonesia yang berjumlah 262 juta orang. ${ }^{.}$Semakin banyaknya penggunaan internet di Indonesia tidak hanya memberikan keuntungan, akan tetapi juga kerugian akibat penyalahgunaan media internet sebagai sarana melakukan kejahatan, termasuk pornografi. Adebayo \& Ojedokun ${ }^{2}$ menegaskan pengguna internet semakin mudah terpapar pornografi melalui penyebarluasan pornografi di internet, baik secara sukarela, maupun tidak sukarela sebagai bagian dari situasi dunia internet.

Penyebarluasan pornografi melalui internet merupakan perbuatan yang dilarang berdasarkan Pasal 27 ayat (1) juncto Pasal 45 ayat (1) UndangUndang Nomor 11 Tahun 2008 tentang Informasi dan Transaksi Elektronik (selanjutnya ditulis UU ITE) sebagaimana telah diubah dengan UndangUndang Nomor 19 Tahun 2016 tentang Perubahan UU No. 11 Tahun 2008 (selanjutnya ditulis UU ITE Perubahan) serta Pasal 4 ayat (1) juncto Pasal 29 ayat (1) Undang-Undang Nomor 44 Tahun 2008 tentang Pornografi (selanjutnya ditulis UU Pornografi). Kedua ketentuan hukum pidana tersebut samasama melarang perbuatan menyebarluaskan pornografi karena melanggar kesusilaan yang semakin mudah dilakukan melalui media internet. ${ }^{3}$ Artinya, larangan perbuatan penyebarluasan pornografi melalui internet atau cyberpornography menyangkut berbagai macam bentuk perbuatan, antara lain membuat, menyebarluaskan, dan menginformasikan materi yang melanggar moral. ${ }^{4}$ Perbuatan revenge porn pun masuk dalam ruang lingkup kedua ketentuan hukum pidana tersebut sebagai perbuatan yang dilarang dan melanggar kesusilaan. ${ }^{5}$

Istilah 'revenge porn' dimaknai sebagai "the distribution of sexually graphic images of individuals without their consent" 6 atau "the sharing of intimate images without the consent of the person depicted..." . Singkat kata "revenge porn' dimaknai sebagai penyebarluasan informasi bermuatan pornografi tanpa adanya persetujuan, terutama oleh korban.

Jika dicermati sebenarnya penyebarluasan pornografi tersebut berawal dari persetujuan korban sebagai salah satu pihak yang berkontribusi dalam pembuatan pornografi sebagai kepentingan diri. Persetujuan korban dalam hal ini dimungkinkan mengingat pembuatan pornografi untuk kepentingan sendiri dikecualikan dari larangan pornografi berdasarkan Penjelasan Pasal 4 ayat (1) UU Pornografi. Pengecualian tersebut memposisikan pembuatan pornografi untuk kepentingan sendiri diperbolehkan sepanjang tidak disebarluaskan. Pembuatan pornografi untuk kepentingan sendiri pada dasarnya dilakukan dengan persetujuan kedua belah pihak, terkait dengan substansi informasi yang dibuat maupun tujuan pembuatan informasi tersebut. Kedua belah pihak menempatkan diri sebagai pembuat informasi bermuatan pornografi tersebut. Kedua belah pihak juga menyetujui pembuatan tersebut untuk dokumentasi pribadi, bukan untuk disebarluaskan. Pada kasus revenge

Asosiasi Penyelenggara Jasa Internet Indonesia, "Info Grafis Hasil Survey 2017”, https://apjii.orid/content/read/39/342/Hasil-SurveiPenetrasi-dan-Perilaku-Pengguna-Internet-Indonesia-2017, diakses 10 April 2018.

Haleemah Bukola Adebayo, et al., "Trajectories of University of Ibadan Undergraduates' Exposure to Cyber Pornography”, Journal of Social, Behavioral and Health Sciences, Vol. 12, Issue 1, 2018, hlm. 145.

Walter S DeKeseredy, "Critical Criminological Understandings of Adult Pornography and Woman Abuse: New Progressive Directions in Research and Theory”, International Journal for Crime, Justice and Social Democracy, Vol. 4, No. 4, 2015, hlm. 6.

Mu'azu Abdullahi Saulawa, "Cyberpornography: an Analysis of the Legal Framework", Global Journal of Politics and Law Research, Vol. 3, No. 2, April 2015, hlm. 45-46.

Hwian Christianto, "Revenge porn sebagai Kejahatan Kesusilaan Khusus: Perspektif Sobural”, Jurnal Veritas et Justitia, Vol. 3, No. 2, Desember 2017, hlm. 302-309.

Shigenori Marsui, “The Criminalization of Revenge Porn in Japan”, Washington International Law Journal Association, Vol. 24, No. 2, April 2015, hlm. 289.

Tyrone Kirchengast, “The Limits of Criminal Law and Justice: 'revenge porn' Criminalization, Hybird Responses and The Ideal Victim”, UniSA Student Law Review, Vol. 2, No. 42, December 2016, hlm. 96. 
porn, penyebarluasan informasi bermuatan pornografi tersebut dilakukan oleh salah satu pasangan dengan tujuan membalas dendam atas sakit hati yang dilakukan oleh pasangannya.

Pemahaman dalam tataran teori viktimologi, pembuatan pornografi untuk kepentingan sendiri walaupun disetujui oleh kedua belah pihak tetap terdapat korban. Ezzat A. Fattah ${ }^{8}$ menjelaskan keterkaitan korban dengan kejahatan yang terjadi dalam 5 (lima) bentuk, yaitu Pertama Non participating victims yaitu korban yang menggangap bahwa kejahatan tidak ada dan dirinya tidak akan terkena kejahatan, Kedua Latent or Predisposed Victims yaitu seorang yang karakternya memudahkan dirinya menjadi korban kejahatan,

Ketiga Provocative Victims yaitu orang karena kondisi atau tingkah lakunya memicu terjadinya kejahatan, Keempat Participating Victims yaitu orang yang menjadi korban karena tingkah lakunya sendiri, dan Kelima False Victims yaitu orang yang menjadi korban karena kehendaknya sendiri.

Berdasarkan kelima pilihan bentuk korban tersebut, siapa yang menjadi korban dalam revenge pornography pun sangat bervariasi jika melihat pada tahap mana perbuatan itu dilakukan. Misalnya saja, ketika pembuatan pornografi untuk kepentingan sendiri dari perspektif viktimologi, kedua belah pihak dapat dikategorikan sebagai korban dalam bentuk latent or predisposed victims, provocative victims, participating victims bahkan false victims. Hanya saja pada kondisi revenge porn ketika materi pornografi telah tersebarluas, korban revenge porn pun semakin sulit ditentukan dalam tataran konsep viktimologi. Hal tersebut mengingat korban sendiri dipandang sebagai pelaku yang ikut menyetujui dan dianggap memahami risiko tersebarluasnya materi pornografi.

Seseorang yang merasa dirugikan atau menjadi korban secara khusus dalam revenge pornography merasa malu dan tekanan psikologis yang besar akibat cyber-bullying 9 dari penyebaran pornografi di media internet. Kondisi tersebut rupanya dipahami pembentuk undang-undang dengan melakukan perubahan UU ITE terkait hak untuk dihapuskan informasi yang merugikan bagi seseorang. Ketetuan hukum tersebut diatur dalam Pasal 26 ayat (1), (2) dan (3) UU ITE yang mengatur:

(1) Kecuali ditentukan lain oleh peraturan perundang-undangan, penggunaan setiap informasi melalui media elektronik yang menyangkut data pribadi seseorang harus dilakukan atas persetujuan Orang yang bersangkutan.

(2) Setiap Orang yang dilanggar haknya sebagaimana dimaksud pada ayat (1) dapat mengajukan gugatan atas kerugian yang ditimbulkan berdasarkan Undang-Undang ini;

(3) Setiap Penyelenggara Sistem Elektronik wajib menghapus Informasi Elektronik dan/atau Dokumen Elektronik yang tidak relevan yang berada di bawah kendalinya atas permintaan Orang yang bersangkutan berdasarkan penetapan pengadilan.

Ketentuan hukum tersebut memberikan hak bagi pihak yang merasa dirugikan sebagai akibat penggunaan informasi elektronik di media elektronik. Hak yang diatur ada 3 (tiga) bentuk, yaitu hak untuk memberikan persetujuan atas informasi yang ditampilkan di media internet, hak untuk meminta ganti rugi, serta hak atas penghapusan informasi yang merugikan dirinya oleh penyelenggara sistem elektronik. Terkait hak terakhir ini dapat dimaknai sebagai hak untuk dilupakan yang masih membutuhkan pemahaman lebih lanjut. Pengaturan tersebut di satu sisi menunjukkan upaya pemerintah memberikan perlindungan kepada korban, secara khusus korban

\footnotetext{
Ezzat Abdel Fattah, "Towards A Criminological Classification of Victims", Criminology and Police Science Journal, Vol. 58, No. 4, December 1967, hlm. 162-169.

9 Meghan Fay, "The Naked Truth: Insufficient Coverage for Revenge Porn Victims at State Law and the Proposed Federal Legislation to Adequately Redress Them", Boston College Law Review, Vol. 59, No. 5, 2018, hlm. 1863.
} 
revenge porn terkait hak untuk dilupakan. Namun di sisi lain juga masih menimbulkan ketidakjelasan atas pengakuan kedudukan korban yang bertalian erat dengan pemenuhan hak untuk dihapuskan atas informasi yang dinilai merugikannya.

Sebuah kasus penyebarluasan pornografi menegaskan kesulitan ini. AS menyebarluaskan foto telanjang mantan kekasihnya melalui media sosial. AS memiliki 16 foto bugil (payudara, belahan payudara, dan alat kelamin) korban yang diperoleh selama berpacaran. Korban kemudian memutuskan AS, sehingga karena merasa sakit hati, AS menyebarkan foto tersebut melalui media sosial Facebook melalui akun Kusuma Furry melalui akun Fitria Saida dan media sosial Whatsapp dalam grup Social A2013 melalui sarana telpon genggam Iphone 4. Perbuatan tersebut dinilai oleh hakim sebagai perbuatan menyebarluaskan informasi bermuatan pornografi sesuai UU Pornografi. ${ }^{10}$ Berdasarkan kasus tersebut tampak bahwa tujuan dilakukannya penyebarluasan informasi bermuatan pornografi sangat khusus untuk melakukan balas dendam atas perbuatan korban. Pelaku telah dipidana, hanya saja foto bugil korban masih beredar di masyarakat.

Kasus serupa juga ditemukan pada kasus EW yang menyebarluaskan foto pasangan nikah sirinya. EW sering mengambil foto badan telanjang korban maupun foto bersama dirinya dengan telpon genggam miliknya. Foto tersebut juga dikirim ke korban sesuai permintaan korban, hingga korban memutuskan hubungan pernikahannya. EW merasa sakit hati lalu mengunggah foto tersebut ke akun Facebook dengan akun "EDI WOJOD". ${ }^{11}$ Serupa tapi tak sama, pembuatan pornografi dilakukan melalui persetujuan kedua belah pihak yang terikat dalam ikatan pernikahan siri. Foto-foto tersebut pun telah diketahui masyarakat melalui akun Facebook walaupun kemudian hari diblokir aksesnya selama proses peradilan. Tujuan dilakukannya perbuatan revenge porn tetap sama untuk membalaskan sakit hati pelaku.

Korban pun mengalami penderitaan mental/ psikologis, keuangan, dan penderitaan fisik $^{12}$ maupun diskriminasi berupa pelecehan seksual melalui media sosial ${ }^{13}$ akibat tersebarnya informasi bermuatan pornografi didukung persepsi pornografi selalu melibatkan tubuh dan persepsi seksualitas. ${ }^{14}$ Ia harus menghadapi cemoohan masyarakat, stigma negatif dari masyarakat, bahkan dikucilkan oleh masyarakat sebagai pelaku pornografi. Bahkan korban revenge porn pun menjadi perhatian masyarakat secara khusus karena terkait foto yang menampilkan ketelanjangan, pemahaman akan foto yang sebenarnya merupakan hal privasi seseorang, dan pandangan bahwa korban revenge porn bersalah dan patut direndahkan. ${ }^{15}$

Kondisi tersebut semakin diperparah dengan sulitnya melakukan penghapusan informasi bermuatan pornografi dari media internet yang semakin tersebar luas. Pihak korban harus berupaya secara mandiri untuk melakukan pengecekan akun pertama penyebar informasi dengan bekal pengetahuan teknologi informasi yang terbatas. Pihak penyedia jasa layanan internet pun tidak akan menghapus informasi bermuatan pornografi secara otomatis. Pihak korban yang merasa dirugikan akibat suatu informasi harus mengupayakan permohonan penghapusan informasi tersebut dengan alasan yang dapat diterima. Proses penghapusan informasi juga membutuhkan waktu yang lama padahal informasi

10 Putusan Pengadilan Negeri Malang Nomor 645/Pid.Ss/2015/PN.Mlg perihal Penyebarluasan Informasi Bermuatan Pornografi, 21 November 2015, hlm. 11-13.

11 Putusan Pengadilan Negeri Mojokerto Nomor 425/Pid.Ss/2015/PN.Mjk perihal Penyebarluasan Foto Pornografi, 24 November 2015, hlm. 12-14.

12 JoAnne Sweeny, "Gendered Violence and Victim-Blaming: The Law's Troubling Response to Cyber-Harassment and Revenge Pornography", International Journal of Technoethics, Vol.8, Issue: 1, 2017, hlm. 3-6.

13 Ita Iya Pulina Perangin-angin, Rahayu, et al., "Kewajiban dan Tanggung Jawab Negara Memberikan Perlindungan Hukum terhadap Perempuan Korban Revenge Porn di Indonesia”, Diponegoro Law Journal, Vol. 8, No. 1, 2019, hlm. 472-473.

14 Patrick Keilty, "Embodied Engagements with online pornography”, The Information Society, Vol. 32, No. 1, 2016 , hlm. 68-69.

15 Zak Franklin, "Justice for Revenge Porn Victims: Legal Theories to Overcome Claims of Civil Immunity by Operators of Revenge Porn Websites", California Law Review, Vol. 102, 2014, hlm.1306. 
bermuatan pornografi tersebut telah tersebar luas di internet. Berdasarkan paparan kondisi pengaturan hak untuk dilupakan terkait korban revenge porn tersebut lebih lanjut dikaji beberapa hal penting, Pertama arti penting hak untuk dilupakan bagi perlindungan korban, serta Kedua mekanisme penerapan hak untuk dilupakan.

\section{B. Metode Penelitian}

Penelitian ini merupakan penelitian hukum ${ }^{16}$ yang diselenggarakan di Provinsi Jawa Timur melalui 3 (tiga) pendekatan, yaitu pendekatan perundang-undangan melalui pemahaman ketentuan hukum yang berlaku, baik dari sisi hiearkhi, maupun ruang lingkup pengaturan ketentuan hukum. ${ }^{17}$ Pendekatan historis melalui pemahaman filosofi dan pertimbangan pembentuk undang-undang pada saat proses pembentukan peraturan perundang-undangan ${ }^{18}$ dan pendekatan konseptual melalui pemahaman doktrin-doktrin atau pandangan yang berkembang dalam ilmu hukum. ${ }^{19}$ Pendekatan perundang-undangan dilakukan dengan pemahaman ketentuan hukum yaitu (1) UU ITE dan (2) Undang-Undang Nomor 13 Tahun 2006 tentang Perlindungan Saksi dan Korban (selanjutnya ditulis UU Perlindungan Saksi dan Korban).

Perihal revenge porn diperoleh dari UU Pornografi yang menampung secara umum konsep pornografi, secara khusus Pasal 4 ayat (1) UU Pornografi. Demi melengkapi pemahaman terkait hak untuk dilupakan dilakukan pendekatan historis atas pembentukan peraturan perundang-undangan yang dikaji dalam kaitannya dengan revenge porn sebagai bagian perbuatan yang dilarang. Pendekatan historis dilakukan dengan mempelajari pertimbangan pembentuk undang-undang akan ruang lingkup UU ITE dan UU Pornografi di dalam Naskah Akademik dan Risalah Sidang Pembahasan
RUU ITE dan RUU Anti Pornografi dan Pornoaksi. Pendekatan konseptual dilakukan dengan melakukan pemahaman atas konsep korban sebagaimana dipahami dalam viktimologi melalui literatur yang diperoleh dari buku, hasil penelitian, dan jurnal sebagai rujukan atas pemahaman hak untuk dilupakan terkait korban, hak korban, dan revenge porn. Pendekatan konseptual ditujukan untuk memahami konsep hak untuk dilupakan sebagai hak korban yang bermula dari pertimbangan hakim atas pengajuan penghapusan video pornografi secara personal. Sedangkan saat ini telah mengalami perkembangan pemahamannya sebagai bagian dari hak seseorang yang dirugikan sebagaimana diatur dalam Pasal 26 UU ITE. Hasil pendekatan perundang-undangan dilengkapi pendekatan historis akan dibandingkan dengan hasil dari pendekatan konseptual untuk memperoleh kesimpulan ada atau tidak adanya kesesuaian dari regulasi terkait hak untuk dilupakan dengan konsep dari hak untuk dilupakan. Akhirnya diperoleh kesimpulan dari pembahasan yang ada untuk menjawab rumusan masalah demi pemenuhan hak untuk dilupakan bagi korban revenge porn.

Terkait dengan penggunaan data, penelitian ini menggunakan data primer berupa peraturan perundang-undangan terkait revenge porn yaitu UU ITE dan UU Pornografi disertai naskah akademik dan risalah pembentukan peraturan perundang-undangan yang diperoleh secara langsung dari narasumber secara langsung, dan halaman internet ppid.dpr.go.id. Data sekunder dalam penelitian ini meliputi bahan hukum primer berupa Undang-Undang Dasar Negara Republik Indonesia Tahun 1945, UU ITE, UU Pornografi, UU Perlindungan Saksi dan Korban, serta putusan pengadilan atas perkara penyebarluasan informasi bermuatan kesusilaan melalui media internet yang

\footnotetext{
Penelitian hukum merupakan upaya menemukan kebenaran koherensi antara aturan hukum dengan norma hukum, norma hukum dan prinsip hukum dan tindakan seseorang bersesuaian dengan norma hukum atau prinsip hukum. Peter Mahmud Marzuki, 2016, Penelitian Hukum, Kencana Prenada Media Group, Jakarta, hlm. 47.

Ibid., hlm. 136-137.

Ibid., hlm.166-167.

Ibid., hlm.177-178.
} 
diperoleh secara langsung dari instansi Pengadilan Negeri Mojokerto dan Pengadilan Negeri Malang Wilayah Hukum Jawa Timur. Selain bahan hukum primer, bahan hukum sekunder yang digunakan berupa buku dan artikel jurnal internasional serta nasional yang menjelaskan pemahaman hak untuk dilupakan dalam konteks revenge porn. Ditambah bahan hukum sekunder, berupa Kamus Besar Bahasa Indonesia untuk menjelaskan istilah yang dipergunakan.

\section{Hasil Penelitian dan Pembahasan 1. Posisi Korban Revenge Porn}

Pemahaman terhadap istilah 'korban' menurut Kamus Besar Bahasa Indonesia (yang selanjutnya disebut KBBI) diartikan sebagai "orang yang menderita (mati dan lain sebagainya) akibat suatu kejadian, perbuatan jahat, dan lain sebagainya". ${ }^{20}$ Senada dengan arti korban tersebut, Pasal 1 angka 2 UU Perlindungan Saksi dan Korban menjelaskan 'korban' sebagai 'seseorang yang mengalami penderitaan fisik, mental dan/ atau kerugian ekonomi yang diakibatkan oleh suatu tindak pidana." Ruang lingkup korban dibatasi pada pihak yang berada dalam kondisi menderita dalam bentuk fisik, mental, dan/atau ekonomi sebagai akibat tindak pidana. Artinya, seseorang dapat disebut sebagai korban dalam ruang lingkup hukum pidana sangat bergantung pada perbuatan yang dilarang oleh ketentuan hukum pidana. Pemahaman akan korban tindak pidana tidak dapat dilepaskan dari pemahaman perbuatan apa yang dilarang oleh Undang-undang, demikian pula revenge porn.

Sebelum membahas ketentuan hukum pidana atas perbuatan revenge porn, perlu dipahami terlebih dahulu bentuk perbuatan tersebut. Perbuatan revenge porn dijelaskan Marsuri ${ }^{21}$ sebagai "the practice of posting and distributing sexually explicit images of an ex-partner on the Internet after a breakup".
Pengertian ini menekankan ciri khas perbuatan pada perolehan informasi tanpa persetujuan orang terkait serta memiliki muatan melanggar kesusilaan dan tujuan dilakukannya perbuatan untuk membalas dendam. Penyebutan revenge porn sendiri di antara para ahli hukum sangat beragam. Ada yang menyebutnya 'non-consensual pornography' atau 'involuntary pornography'. ${ }^{22}$ Kedua pengertian tersebut memiliki perbedaan dalam hal ciri yang ditekankan dari perbuatan revenge porn.

Pandangan pertama lebih menekankan revenge porn sebagai perbuatan menyebarluaskan gambar yang memuat tampilan seksual secara eksplisit dari mantan pasangan. Bagi pandangan pertama, revenge porn termasuk dalam penyebarluasan infomasi yang melanggar kesusilaan dalam kondisi khusus, yaitu berupa gambar (images) dan objeknya mantan pasangan. Berbeda halnya dengan pandangan kedua, revenge porn memiliki ciri khas tidak adanya persetujuan korban untuk menyebarluaskan informasi (images) yang memiliki muatan pornografi. Jika dibandingkan, di antara kedua pandangan tersebut sama-sama menekankan revenge porn sebagai perbuatan menyebarluaskan informasi bermuatan pornografi. Hanya saja dari sisi ruang lingkup, pandangan pertama terbatas pada informasi dalam bentuk gambar (images) tidak dalam bentuk lain, teks, rekaman video, rekaman suara, atau bentuk lainnya. Kelemahan pandangan pertama justru hanya menekankan kondisi revenge porn dari perolehan gambar pornografi dari korban yang merupakan mantan pasangannya. Tidak diuraikan dengan jelas kondisi korban memberikan persetujuan atau tidak terhadap gambar yang diambil dapat disebarluaskan ataukah tidak.

Persetujuan memang diberikan untuk membuat gambar diri dan/atau pasangan dalam keadaan telanjang atau dalam keadaan yang melanggar kesusilaan. Sebuah penelitian menarik 
dari Hald dan Štulhofer ${ }^{23}$ menegaskan kecenderungan pornografi lebih besar pada laki-laki heteroseksual daripada perempuan heterseksual, sehingga pembuatan pornografi pun sering terjadi. Akan tetapi tidak dapat dipahami juga bahwa korban tidak memberikan persetujuan bahwa gambar tersebut di kemudian hari akan disebarluaskan. Demi memperjelas pemahaman akan kedudukan korban dalam revenge porn, berikut akan disajikan bagan alur perbuatan revenge porn.

\section{Bagan 1.}

\section{Alur Perbuatan Revenge Porn}

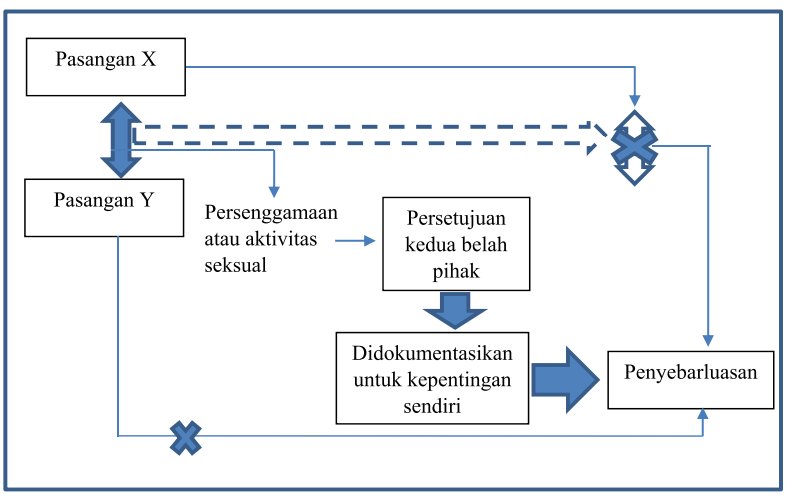

Sumber: Diolah oleh Penulis, 2019

Berdasarkan pemahaman atas alur perbuatan revenge porn tersebut maka ada perubahan kondisi dari sisi persetujuan korban, semula menyetujui pembuatan pornografi, tetapi di kemudian hari secara sepihak pelaku tanpa persetujuan korban lalu menyebarluaskan pornogarfi tersebut. Dengan demikian, kembali pada pandangan kedua hanya menekankan larangan perbuatan revenge porn bahwa perbuatan penyebarluasan itu tidak mendapat persetujuan dari pihak yang menjadi model pornografi. Istilah 'non-consensual pornography' atau 'involuntary pornography' hanya menerangkan tidak adanya persetujuan dari seseorang yang menjadi model pornografi. Kedua istilah tersebut sama sekali tidak menjelaskan bahwa perolehan informasi bermuatan pornografi berasal dari hubungan asmara dari pelaku penyebaran dan korban itu sendiri.

Penulis sendiri berpandangan bahwa kedua pandangan tersebut dapat dipadukan sebagai pemahaman revenge porn dengan 3 (tiga) ciri khas, yaitu pertama, perbuatan penyebarluasan informasi bermuatan pornografi; kedua, perolehan informasi bermuatan pornografi dari hubungan asmara antara pelaku dan korban; dan ketiga, tujuan perbuatan untuk membalaskan sakit hati atau dendam pelaku akibat perbuatan korban kepada dirinya. Ciri pertama menekankan revenge porn sebagai bagian dari perbuatan menyebarluaskan informasi yang memiliki muatan melanggar kesusilaan. Perihal perbuatan menyebarluaskan informasi yang memiliki muatan melanggar kesusilaan dapat disamakan dengan perbuatan sexting. Istilah 'sexting' dipahami sebagai perpaduan dua istilah "sex" dan "texting" ${ }^{24}$, yaitu perbuatan mengirim, menerima atau mengirimkan ulang pesan yang mengandung unsur seksual atau ketelanjangan, setengah telanjang atau gambar seks dari diri sendiri atau orang lain melalui telepon genggam, surat elektronik, internet atau layanan media sosial. ${ }^{25}$ Berdasarkan definisi "sexting" tersebut, perbuatan revenge porn dapat masuk di dalamnya.

Ciri kedua, cara memperoleh informasi yang memiliki muatan yang melanggar kesusilaan menjadi ciri khas kedua dari revenge porn. Pelaku mendapatkan informasi yang memiliki muatan melanggar kesusilaan tidak dengan melakukan perbuatan melawan hukum, seperti pemaksaan, perkosaan, ancaman, atau penipuan. Pelaku dan korban merupakan pasangan kekasih yang

23 Gert Martin Hald \& Aleksandar Štulhofer, "What Types of Pornography Do People Use and Do They Cluster? Assesing Types and Categories of Pornography Consumption in a Large-Scale Online Simple”, Journal of Sex Research, Vol. 53, No. 7, 2016 , hlm. 852.

24 K. Jaishankar, "Sexting: A New Form of Victimless Crime?", International Journal of Cyber Criminology, Vol. 3, Issue 1, Januari-Juni 2009, hlm. 21.

25 Fawn T. Ngo, et al., "Sexting: Current Research Gaps and Legislative Issue: General Editors' Introduction to the Special Issue", International Journal of Cyber Criminology, Vol. 11, Issue 2, Juli-Desember 2017, hlm. 162. 
menghendaki dibuatnya informasi yang isinya diketahui pula melanggar kesusilaan. Artinya, baik pelaku dan korban memiliki pengetahuan bahwa informasi yang dibuat memiliki muatan yang melanggar kesusilaan, demikian pula keduanya menyetujui pembuatan informasi tersebut. Penting untuk dipastikan bahwa pelaku memperoleh informasi yang mengandung muatan melanggar kesusilaan juga dalam rentang waktu pelaku dan korban masih dalam hubungan asmara, serta adanya persetujuan korban. Perihal bentuk dan muatan informasi yang melanggar kesusilaan pada dasarnya sangat beragam dapat berupa gambar, kartun, animasi, teks, rekaman suara ataupun rekaman video. Penggunaan istilah 'informasi yang melanggar kesusilaan' dapat memuat semua bentuk informasi yang dibuat oleh pelaku maupun korban.

Terkait dengan ciri ketiga, tujuan membalaskan dendam atau sakit hati pelaku atas perbuatan korban menjadi tujuan disebarluaskannya informasi yang memuat pelanggaran kesusilaan. Penyebarluasan informasi yang mengandung muatan melanggar kesusilaan tidak semata-mata ditujukan supaya orang lain mengetahui informasi asusila. Penyebarluasan informasi memiliki motif yang jelas supaya korban merasa malu atau rusak kehormatannya menjadi model pornografi.

Berdasarkan pemahaman akan ketiga ciri revenge porn tersebut korban pada mulanya ikut berperan serta dalam pembuatan informasi yang melanggar kesusilaan. Bersama dengan pelaku ia menyetujui dalam keadaan mengetahui pembuatan informasi memiliki muatan yang melanggar kesusilaan dan menghendaki pembuatan tersebut. Ia menyetujui pembuatan informasi mengandung muatan yang melanggar kesusilaan untuk kepentingan sendiri. Perihal pembuatan pornografi untuk kepentingan sendiri memang dikecualikan dari larangan pornografi sebagaimana diatur dalam Penjelasan Pasal 4 ayat (1) UU Pornografi. Artinya, ia tidak dapat dimasukkan dalam kategori korban perbuatan pornografi secara yurudis normatif. Walaupun demikian, seseorang menjadi model atau pemeran adegan dipandang dari sisi teori viktimologi. ${ }^{26}$ Pemahaman teori viktimologi ini nantinya akan dibahas dalam pandangan ahli viktimologi terkait bentuk korban terkait dengan kejahatan yang terjadi pada dirinya.

Pemikiran akan pentingnya melibatkan korban dalam pemahaman kejahatan tidak dapat dilepaskan dari Deklarasi PBB tahun 1985 Nomor 40/34 tanggal 29 November 1985 tentang Declaration of Basic Principles of Justice for Victims of Crime and Abuse of Power (selanjutnya ditulis Deklarasi PBB Tahun 1985). Berdasarkan deklarasi tersebut peran serta korban dalam kejahatan terkait erat dengan viktimisasi, baik karena keadaan maupun perbuatan pelaku kejahatan. ${ }^{27}$ Artinya, korban tetap dipandang penting diperhatikan peran dan kedudukannya atas kejahatan yang terjadi.

Sebagaimana telah dikemukakan sebelumnya, 5 bentuk korban terkait kejahatan oleh Ezzat A. Fattah ${ }^{28}$ yaitu Non-participating Victims (korban yang menggangap bahwa kejahatan tidak ada dan dirinya tidak akan terkena kejahatan), Latent or Predisposed Victims (seorang yang karakternya memudahkan dirinya menjadi korban kejahatan), Provocative Victims (orang karena kondisi atau tingkah lakunya memicu terjadinya kejahatan), Participating Victims (orang yang menjadi korban karena tingkah lakunya sendiri), dan False Victims (orang yang menjadi korban karena kehendaknya sendiri).

\footnotetext{
26 Viktimologi memandang adanya hubungan antara pelaku dan korban atas terjadinya kejahatan (revenge porn), orientasi utama pada korban selain perbuatan dan pelaku (daad-dader-slachtoffer) karena korban memiliki andil atas kejahatan yang terjadi baik kecil maupun besar tetapi menentukan. Mudzakkir, "Perkembangan Viktimologi dan Hukum Pidana", Makalah, Pelatihan Hukum Pidana dan Krimilogi Kerjasama Fakultas Hukum UGM dan Masyarakat Hukum Pidana dan Kriminologi Indonesia (MAHUPIKI), Yogyakarta, 23-27 Februari 2014, hlm. 4.

27 T. Newburn, 2007, Criminology, Willan Publishing, Portland, hlm. 342.

28 Ezzat Abdel Fattah, "Towards A Criminological Classification of Victims", Criminology and Police Science Journal, Vol. 58, No. 4, December 1967, hlm 162-169.
} 
Tipologi korban berbeda dikemukakan oleh Stephen Scafer $^{29}$ yang membagi bentuk korban dalam 6 (enam) bentuk, yaitu Unrelated Victims yaitu orang yang tidak memiliki peran dalam kejahatan; Provocative Victims yaitu orang yang memudahkan dirinya menjadi korban kejahatan; Precipitative Victims yaitu orang yang secara tidak langsung membuat orang lain melakukan kejahatan pada dirinya; Biologically Weak Victims yaitu orang menjadi korban karena kondisi fisiknya; Socially Weak Victims yaitu orang yang menjadi korban karena tidak mendapat perhatian dalam masyarakat; serta Self Victimizing Victims yaitu orang yang menjadi korban karena dirinya sendiri pelakunya. Jika diamati kedua macam tipologi korban tersebut menekankan hal yang sama terkait kontribusi seseorang menjadi korban kejahatan. Perbedaan terdapat dalam model korban Scafer yang membagi latent or predisposed victim dalam 2 (dua) bagian yaitu faktor kondisi fisik dan faktor kondisi sosial atas korban.

Seseorang baru menjadi korban revenge porn pada saat informasi yang memuat pelanggaran kesusilaan disebarluaskan tanpa persetujuan dirinya. Korban dalam situasi demikian diciderai janjinya tentang tujuan pembuatan informasi yang memiliki muatan melanggar kesusilaan untuk kepentingan sendiri. Akibat penyebarluasan informasi yang melanggar kesusilaan korban mengalami tekanan secara mental dengan adanya nama baik yang dicemarkan, stigma negatif dari masyarakat karena ikut serta dalam pembuatan pornografi dan materi informasi yang terus beredar luas di media internet (victim blamming). ${ }^{30}$ Posisi korban dalam revenge porn lebih lanjut dapat dikaji berdasarkan tipologi korban sebagaimana ditegaskan Ezzat A. Fattah dan Stephen Scafer. Korban pada dasarnya memiliki pengetahuan akan dirinya menjadi model pornografi atas dasar relasi cinta dengan pelaku. Kondisi tersebut menunjukkan korban mempermudah diri untuk difoto atau direkam menjadi model pornografi. Kemudahan yang diberikan korban revenge porn tampak dengan jelas dari persetujuan yang diberikan, bahkan tanpa penolakan atau perlawanan atas perbuatan mendokumentasikan pornografi.

Artinya, korban revenge porn berada dalam bentuk Latent or Predisposed Victims atau Provocative Victims. Tidak hanya itu jika diperhatikan korban justru karena perbuatannya menjadi korban revenge porn sendiri (Participating Victims). Berdasarkan pemahaman tersebut korban memang memiliki kontribusi atas kejahatan revenge porn. Hanya saja pemahaman akan peran korban, baik dalam bentuk Predisposed Victims dan Participating Victims tidak sejalan dengan Penjelasan Pasal 4 ayat (1) UU Pornografi. Secara yuridis normatif, pembuatan pornografi untuk kepentingan sendiri dikecualikan atas larangan pornografi. UU Pornografi jelas mengabaikan kedudukan dan peran serta korban dalam revenge porn dan hanya berfokus pada pelaku yang membuat pornografi.

\section{Konsep Hak untuk Dilupakan (Right to be Forgotten)}

Hak dan hukum sebenarnya tidak dapat dipisahkan. Pengaturan akanhukumpada hakikatnya merupakan pengaturan akan hak yang dimiliki oleh setiap orang. Machmud Marzuki ${ }^{31}$ menegaskan hal ini dari sisi penggunaan istilah hak dan hukum dengan istilah yang sama yaitu ius (bahasa Latin), droit (bahasa Perancis) dan recht (bahasa Belanda) lebih lanjut dalam penggunaannya dibedakan dengan penggunaan subjective recht untuk hak dan objective recht untuk hukum. Berdasarkan hal tersebut pengertian akan 'hak' dipahami sebagai sesuatu yang melekat pada manusia terkait

\footnotetext{
Stephen Scafer, The Beginning of Victimology in IBurt Galaway, et al., 1981, Perspectives on Crime Victims, Mosby, St. Louis, hlm. $10-19$. Tegan S. Starr, et al., "Perceptions of Revenge Pornography and Victim Blame", International Journal of Cyber Crimininology, Vol. 12, Issue 2, July-December 2018, hlm. 428-429.

31 Peter Machmud Marzuki, 2008, Pengantar Ilmu Hukum, Kencana Prenada Media Group, Jakarta, hlm. 165.
} 
dengan dua kebutuhan, yaitu kebutuhan fisik dan kebutuhan akan eksistensi. ${ }^{32}$ Hak untuk dilupakan sebenarnya merupakan hal yang sangat berkaitan erat dengan eksistensi diri. Pengakuan akan hak untuk dilupakan dalam Undang-Undang Dasar Nergara Republik Indonesia Tahun 1945 tidak secara eksplisit diatur. Pemahaman akan hak untuk dilupakan dapat dikaitkan dengan hak asasi manusia terkait perlindungan hukum dan pengakuan diri. Pemikiran terhadap hak untuk dilupakan tidak dapat dilepaskan dari hak privasi dalam penggunaan teknologi informasi.

Eksistensi hak privasi sebenarnya telah menjadi perhatian dalam hukum dan hak asasi manusia. Thomas Cooley, hakim Amerika Serikat menyebut istilah "the right to be alone" memulai pengakuan privasi. ${ }^{33}$ Deklarasi Universal Hak Asasi Manusia Tahun 1948 (selanjutnya ditulis DUHAM 1948), secara khusus Pasal 3 mengatur bahwa "Setiap orang berhak atas kehidupan, kebebasan, dan keselamatan sebagai individu". ${ }^{34}$ Walaupun rumusan tersebut tidak secara langsung mencantumkan hak privasi, tidak berarti hak privasi tidak diakui. Pemahaman terhadap rumusan Pasal 3 DUHAM 1948 pada dasarnya mengakui kebutuhan diri pribadi manusia atas kehidupan, kebebasan, dan keselamatan. Jika dikaitkan dengan pemahaman hak sebagai jaminan kebutuhan manusia untuk hidup, maka pengakuan atas kebutuhan diri pribadi manusia atas kehidupan dan keselamatan menjadi kebutuhan susbtansi, sedangkan kebutuhan untuk kebebasan menjadi kebutuhan eksistensi. Hak privasi sendiri berposisi sebagai salah satu hak yang dimiliki seseorang untuk eksistensi. Oleh karenanya, pemahaman akan hak privasi dapat dikatakan telah dipikirkan sejak awal dalam

\section{DUHAM 1948.}

Perkembangan hak privasi di Eropa tidak terlepas dari Undang-Undang Hak Asasi Manusia tahun 1998 di Inggris yang membedakan antara penghormatan akan hak privasi untuk publikasi (recognition of privacy) dan perlindungan hak privasi itu sendiri. ${ }^{35}$ Wacks $^{36}$ menegaskan pemahaman ini diadopsi oleh negara-negara eropa seperti terdapat dalam European Convention on Human Rights (ECHR). Darrell ${ }^{37}$ menjelaskan Amerika Serikat pun telah membedakan pemahaman hak privasi dalam artian "right of publicity", yaitu hak untuk mencegah penggunaan nama diri oleh orang lain untuk kepentingan ekonomis tanpa persetujuan dirinya, serta hak privasi dalam artian "privacy right", yaitu hak seseorang untuk merahasiakan diri atau tidak diketahui identitasnya (the right to be left alone). Hak privasi pun dipahami dalam dua wajah berbeda, sebagai hak untuk mempublikasikan diri dan hak untuk merahasiakan diri. Hal yang menarik dari pemahaman akan hak privasi tersebut telah dibedakan antara hak privasi di satu sisi dan penghormatan atas hak privasi orang lain. Lebih lanjut Wacks $^{38}$ menjelaskan kaitan hak privasi dengan penggunaan informasi elektronik merujuk pada pemahaman istilah "personal information" sebagai "what is reasonable for an individual to regard as private and therefore to wish to control or limit use".

Berdasarkan pemahaman tersebut, maka hak privasi terkait dengan data pribadi seseorang yang memiliki arti penting menunjukkan diri sebagai hal yang privasi sehingga terbatas penggunaannya. Dengan demikian, hak privasi memiliki hubungan erat dengan data informasi seseorang termasuk penggunaannya sangat terbatas atas persetujuan

\footnotetext{
Ibid., hlm. 172.

Ridha Aditya Nugraha, "Perlindungan Data Pribadi dan Privasi Penumpang Maskapai Penerbangan pada Era Big Data", Jurnal Mimbar Hukum, Vol. 30, No. 2, Juni 2018, hlm. 263.

Ignatius Bagus Susilo, et al., 2003, Kompilasi Instrumen Internasional Hak Asasi Manusia Berikut Ratifikasinya dalam Peraturan Perundangundangan di Indonesia, Pusat Studi Hak Asasi Manusia Universitas Surabaya, Surabaya, hlm. 3.

Raymond Wacks, 2013, Privacy and Media Freedom, Croydon, Oxford, hlm. 3.

Ibid.

Keith B. Darrell, 2009, Issues in Internet Law: Society, Technology and the Law, Fifth Edition, Amber Book, Washington, hlm.154-155.

Raywomd Wacks, Loc.cit.
} 
pemilik data. Hal berbeda terkait penghormatan atas hak privasi orang lain, penggunaan informasi elektronik seharusnya mempertimbangkan kepemilikan data milik orang lain atau memiliki substansi informasi dengan orang lain yang memiliki resiko kerugian. Misalnya saja penggunaan informasi nama orang lain untuk melakukan penipuan secara daring melalui surat elektronik. Hal ini menjadi perbuatan melanggar hak privasi orang lain karena tidak menghormati hak privasi orang lain. Hak privasi atas penggunaan informasi elektronik pada awalnya dipandang penting karena dikaitkan dengan kepentingan ekonomi dan komersial bukan hak asasi manusia. ${ }^{39}$ Senada dengan pandangan tersebut, $\mathrm{Lim}^{40}$ menjelaskan bahwa pengaturan hak privasi terkait penggunaan internet dipandang penting dari sisi ekonomi tampak dari pengaturan hak privasi di Uni Eropa yang bersifat konvergen dan Amerika Serikat yang bersifat divergen terhadap e-commerce. Perubahan pentingnya hak privasi sebagai keamanan pribadi baru muncul pada saat terjadi kasus penyebarluasan pornografi di Spanyol.

Hak untuk dilupakan atau right to be forgotten dikenal dalam kasus Google Spain SL v Agencia Española de Protección de Datos, Mario Costeja González (2014). Kasus berawal dari keterlibatan Taziana Cantone/TZ, seorang perempuan berusia 30 tahun yang merekam aktivitas seksual dirinya bersama beberapa orang pria sambil mengatakan "Stai facendo il video? Bravo! (You're filming? Bravo!). Video tersebut dikirim oleh dirinya kepada mantan kekasihnya, Sergio di Palo dan 5 (lima) orang teman lainnya melalui media sosial Whatsapp, namun akhirnya beredar luas di media internet, dimuat dalam laman internet dewasa bahkan menjadi viral di media internet. TZ pun mengajukan permohonan untuk memberikan 'right to be forgotten" pada dirinya. Pengadilan Italia memenuhi permohonan TZ dan membebankan biaya sebesar $€ 20,000$. Hanya saja penyedia jasa internet Google Spain SL \& Google Inc. belum melakukan eksekusi atas video yang dimaksudkan, sehingga Lembaga Perlindungan Data Spayol dan ibu TZ mengajukan perkara ini ke Court of Justice of the European Union (selanjutnya ditulis CJEU).

Putusan CJEU No. C-131/12 pada 13 Mei 2014, memberikan penegasan pentingnya penghapusan data elektronik yang memuat informasi merugikan seseorang harus dipenuhi oleh penyedia jasa internet. Kasus tersebut menunjukkan betapa pentingnya pemenuhan hak untuk dilupakan bagi korban pornografi melalui internet. Suatu informasi elektronik dapat dibuat dan disebarluaskan oleh siapapun dan dalam keadaan apapun sehingga rentan menimbulkan korban.

Korban pornografi melalui internet pada dasarnya terdapat3(tiga)bentuk, pertama seseorang yang mengetahui dirinya direkam atau difoto untuk tujuan disebarluaskan di media komunikasi; kedua seseorang yang mengetahui dirinya direkam/difoto, akan tetapi tidak menghendaki hasil rekaman atau foto disebarluaskan di media komunikasi; dan ketiga seseorang yang tidak mengetahui dan tidak menghendaki dirinya direkam atau difoto serta disebarluaskan di media komunikasi. Korban pornografi tidak mungkin dalam posisi tidak mengetahui dirinya didokumentasikan, namun menghendaki dokumentasi tersebut disebarluaskan. Seseorang yang berada dalam kondisi terakhir ini sebenarnya tidak lagi menjadi korban karena dia menyetujui penyebarluasan tersebut.

Korban revenge porn jika dikaitkan dengan tiga bentuk korban tersebut dapat dipahami berada pada bentuk korban kedua, ia mengetahui dirinya difoto/direkam, akan tetapi tidak menghendaki penyebarluasan foto/rekaman tersebut melalui media komunikasi. Hal penting yang menjadi perhatian pada korban seperti yang dialami $\mathrm{TZ}$ terletak pada nama baik yang rusak, penghinaan

\footnotetext{
39 A. Charlesworth, "Data Privacy in Cyberspace: Not National vs International but Commercial vs Individual" dalam L. Edwards L \& C Waelde, ed., 2000, Law and the Internet: A Framework for Electronic Commerce, Second Edition, Hart Publishing, Oxford, hlm. 81-82

40 Yee Fen Lim, 2007, Cyberspace Law: Commentaries and Materials, Second edition, Oxford University Press, New York, hlm. 141-149
} 
sebagai model pornografi, cap buruk dari masyarakat, bahkan penolakan masyarakat. Belum lagi jika diingat karakteristik revenge porn sebagai salah satu bentuk kejahatan siber, rekaman/foto bermuatan asusila akan terus tersebar luas melalui berbagai bentuk platform internet yang sangat sulit terdeteksi. Di dalam kedudukan inilah TZ sebagai korban melakukan actio iniuriarium (perbuatan yang berfungsi untuk melindungi keberadaan seseorang secara eksistensi) untuk menghalangi, mencegah, bahkan menghapus informasi yang merugikan dirinya terutama di internet. ${ }^{41}$

Hal yang menarik dari kasus Google Spain SL $v$ Agencia Española de Protección de Datos, Mario Costeja González (2014) terletak pada konsep hak untuk dilupakan (right to be forgotten) yang diberikan. Putusan CJEU No. C-131/12 pada 13 Mei 2014 menegaskan bahwa hak untuk dilupakan dalam hal ini merupakan hak yang dimiliki oleh seseorang yang dirugikan akibat data elektronik yang dimuat oleh penyedia jasa internet. Berdasarkan hal tersebut, fokus CJEU pada kasus ini terletak pada penghormatan hak privasi yang dimiliki oleh korban. Hal tersebut menjadi penting mengingat pemahaman akan CJEU tersebut selaras dengan putusannya yang mewajibkan penyedia jasa internet, Google Spain SL, menghapus data informasi korban dari search engine miliknya. Kasus tersebut menjadi tonggak pemahaman akan hak untuk dilupakan begitu penting sebagai hak diri pribadi dalam bentuk hak privasi yang harus dihormati oleh orang lain dalam hal penggunaan dan penyebarluasannya. Perkembangan serupa juga dijelaskan oleh Kumar ${ }^{42}$ bahwa pengakuan hak untuk dilupakan atas kasus kekerasan seksual diawali dari pertimbangan hakim atas perkara tersebut. Hal tersebut menegaskan perkembangan pengaturan hak untuk dilupakan di negara lain diawali dari pertimbangan hakim dalam penangan perkara secara aktual.
Berbeda dengan Indonesia yang memulai pengenalan hak untuk dilupakan dari pengaturan undang-undang. Aswari, et al. ${ }^{43}$ menegaskan ketentuan hukum Pasal 26 ayat (3) sampai dengan ayat (5) UU ITE Perubahan secara implisit mengakui hak untuk dilupakan. Walaupun demikian kedua ketentuan hukum tersebut tidak sepenuhnya mengadopsi konsep hak untuk dilupakan pada kasus Google Spain SL v Agencia Española de Protección de Datos, Mario Costeja González. Pemikiran atas hak korban sebenarnya menjadi hal penting dalam UU ITE Perubahan, sebagaimana ditegaskan dalam Penjelasan Pasal 26 ayat (1) UU ITE Perubahan yang menegaskan keberadaan hak pribadi (privacy rights). Pemanfaatan teknologi informasi membawa dampak pada pentingnya perlindungan hak atas pribadi yang dipahami sebagai: a) Hak pribadi merupakan hak untuk menikmati kehidupan pribadi dan bebas dari segala macam gangguan; b) Hak pribadi merupakan hak untuk dapat berkomunikasi dengan Orang lain tanpa tindakan memata-matai; c) Hak pribadi merupakan hak untuk mengawasi akses informasi tentang kehidupan pribadi dan data seseorang.

Berdasarkan hal tersebut, hak pribadi terkait penggunaan informasi teknologi diakui terbatas pada 3 (tiga) hal pokok, yaitu hak untuk menikmati kehidupan pribadi dan bebas dari gangguan, hak berkomunikasi bebas dari tindakan mematamatai, serta hak untuk mengawasi akses informasi tentang kehidupan pribadi dan data yang dimiliki. Ketiga hak pribadi tersebut jika dikaitkan dengan konsep ECHR maka diperoleh pemahaman hak pribadi bentuk pertamalah yang ditegaskan dalam Penjelasan Pasal 26 ayat (1) UU ITE Perubahan. Penjelasan Pasal 26 ayat (1) UU ITE mengatur sebagai berikut:

Dalam pemanfaatan Teknologi Informasi, perlindungan data pribadi merupakan salah satu bagian dari hak pribadi (privacy rights).

\footnotetext{
Jonathan Brown, "Revenge porn' and the actio iniuriarum: using 'old law' to solve 'new problems”, Legal Studies, Vol. 38, 2018 , hlm. 397. Alok Prasanna Kumar, "Right to be Forgotten' in Indian Law", Economic and Political Review, Vol. 52, No. 11, March 2017, hlm. 4.

Aan Aswari, et al., "Harmonisasi Hukum Hak untuk Dilupakan bagi Korban Digital terhadap Calon Mahasiswa di Makassar", Kanun Jurnal Ilmu Hukum, Vol. 20, No. 1, April 2018, hlm. 57.
} 
Hak pribadi mengandung pengertian sebagai berikut: a. Hak pribadi merupakan hak untuk menikmati kehidupan pribadi dan bebas dari segala macam gangguan. b. Hak pribadi merupakan hak untuk dapat berkomunikasi dengan Orang lain tanpa tindakan mematamatai. c. Hak pribadi merupakan hak untuk mengawasi akses informasi tentang kehidupan pribadi dan data seseorang.

Bentuk hak privasi yang diatur lebih ditekankan pada hak menikmati kehidupan pribadi, hak berkomunikasi, dan hak akses informasi tentang kehidupan pribadi dan data seseorang. Hal tersebut menunjukkan penekanan utama terletak pada pengakuan hak pribadi yang dimiliki oleh seseorang. Pengakuan atas hak pribadi bentuk kedua, penghormatan atas hak pribadi orang lain sebenarnya dapat ditemukan dalam rumusan Pasal 26 ayat (3), (4) dan (5) UU ITE Perubahan. Pembentuk undang-undang menegaskan kewajiban tiap penyelenggara sistem elektronik untuk menghapus setiap informasi/dokumen elektronik yang tidak relevan yang berada di bawah kendalinya atas permintaan orang yang bersangkutan.

Ketentuan hukum tersebut menegaskan pentingnya penghormatan atas hak pribadi orang lain secara khusus yang keberatan karena tidak relevan. Berdasarkan pemahaman Pasal 26 ayat (3) UU ITE Perubahan dapat dipahami bahwa penghapusan informasi/dokumen elektronik menjadi suatu kewajiban ketika dimintakan oleh orang yang bersangkutan berdasar penetapan pengadilan karena secara substansi dinilai tidak relevan. Secara harafiah, Pasal 26 ayat (3) UU ITE memang tidak menggunakan istilah "hak untuk dilupakan" akan tetapi "permintaan menghapus Informasi Elektronik dan/atau Dokumen Elektronik yang tidak relevan". Kedua istilah tersebut pada dasarnya memiliki pemaknaan yang sama dengan hak untuk dilupakan. Hal yang menarik pemenuhan hak untuk dilupakan dalam pelaksanaannya harus memenuhi syarat substansi dan syarat administrasi. Syarat substansi yang dimaksudkan merujuk pada informasi/dokumen elektronik tersebut tidak relevan. Pemahaman atas frasa "tidak relevan" tidak dijelaskan dalam UU ITE maupun UU ITE Perubahan.

Penilaian atas batasan informasi/dokumen elektronik tidak relevan jika digunakan prinsip noscitur a sociis, maka dipahami menurut penilaian orang yang bersangkutan dan ditetapkan oleh pengadilan. Oleh karena itu, ukuran penilaian pun sangatlah subjektif tergantung pada pemahaman orang yang menjadi korban. Hal tersebut jika dipahami dari sisi pemenuhan hak korban sebenarnya merupakan langkah yang sangat minim. Korban harus berinisiatif dan berupaya secara mandiri untuk mendapatkan layanan penghapusan informasi/dokumen elektronik yang merugikan dirinya. Pengaturan terhadap batasan konten informasi/dokumen elektronik memang tidak terbatas pada penilaian subjektifitas korban, akan tetapi termasuk informasi/dokumen elektronik yang dilarang oleh UU ITE. Suatu informasi/dokumen elektronik yang dipandang tidak relevan oleh seseorang atau korban tetap beredar di internet.

\section{Mekanisme Penerapan Hak untuk Dilu- pakan}

Ketentuan hukum Pasal 1 UU ITE Perubahan memberikan perubahan pada Pasal 26 yang memberikan pengaturan tentang perlindungan data pribadi yang dimiliki seseorang. Semula Pasal 26 UU ITE hanya menegaskan tentang pentingnya persetujuan orang yang bersangkutan untuk penggunaan informasi dirinya. Perlindungan hukum atas data pribadi masih terbatas pada adanya persetujuan dan penilaian dari orang yang terkait dengan data informasi yang digunakan. Proses penegakan hukum pun diarahkan pada mekanisme litigasi dengan waktu lama, mekanisme bertahap dan biaya yang tidak murah. Kondisi tersebut semakin menempatkan orang yang dirugikan dalam keadaan sulit dan harus mengeluarkan pembiayaan yang mahal. Belum lagi tidak ada kewajiban bagi penyedia jasa untuk menghapus data informasi yang dianggap merugikan tersebut. Informasi merugikan tetap beredar bahkan semakin beredar luas dalam sistem informasi tanpa ada kendali, 
begitu pula dengan kerugian yang dialami korban. Penghapusan data informasi oleh pengguna jasa dapat dilakukan ketika ada permohonan dari korban atau perintah pengadilan untuk itu. Berdasarkan hal tersebut, korban dalam pengaturan UU ITE tampak belum diatur dengan baik.

UU ITE Perubahan memberikan perubahan penting dalam hal perlindungan korban. Prinsip utama perlindungan data pribadi seseorang didasarkan pada persetujuan orang yang bersangkutan (Pasal 26 ayat (1) UU ITE Perubahan) dipahami sebagai satu bagian dari hak pribadi (privacy rights). Penjelasan Pasal 1 angka 3 UU ITE Perubahan menjelaskan pemahaman hak pribadi dalam Pasal 26 UU ITE memiliki 3 (tiga) pengertian, antara lain (a) Hak pribadi merupakan hak untuk menikmati kehidupan pribadi dan bebas dari segala macam gangguan; (b) Hak pribadi merupakan hak untuk dapat berkomunikasi dengan orang lain tanpa tindakan memata-matai; serta (c) Hak pribadi merupakan hak untuk mengawasi akses informasi tentang kehidupan pribadi dan data pribadi seseorang.

Jika diamati, penjelasan dua makna dari hak pribadi tersebut pengaturan perlindungan data pribadi memiliki dua dimensi yang saling terkait satu sama lain, pertama dimensi diri pribadi seseorang dan kedua, dimensi pergaulan diri dengan orang lain. Pemahaman akan perlindungan data pribadi yang dimiliki seseorang di satu sisi merupakan pengakuan hak diri atas kehidupan pribadi namun di sisi lain mempertimbangkan juga relasi dengan orang lain untuk berkomunikasi dan akses atas informasi tentang kehidupan pribadi dan data seseorang. Berdasarkan pemahaman tersebut tampak bahwa Pasal 26 UU ITE Perubahan mempertimbangkan konsep hak asasi manusia sebagaimana diemban dalam Undang-Undang Dasar Negara Republik Indonesia Tahun 1945. Hak untuk dilupakan merupakan bagian dari hak asasi manusia yang dimiliki pribadi untuk memperoleh rasa aman dan perlindungan hukum atas tindakan yang merugikan. Jaminan atas hak untuk dilupakan menjadi bagian penting dalam penggunaan internet mengingat informasi elektronik yang beredar pada hakikatnya merupakan informasi milik seseorang.

Hal yang perlu dipahami lebih lanjut terkait penerapan hak untuk dilupakan yang diterapkan UU ITE Perubahan. Rumusan Pasal 26 UU ITE Perubahan menegaskan tambahan ayat (3), ayat (4), dan ayat (5) tentang perlindungan korban dan prinsip penghapusan informasi elektronik dan/atau dokumen elektronik yang tidak relevan. Pasal 26 ayat (3) dan ayat (4) UU ITE Perubahan menegaskan hal baru terkait perlindungan korban, termasuk korban revenge porn. Hal lain yang baru dalam Pasal 26 UU ITE Perubahan terkait dengan bagian yang harus dikerjakan oleh penyelenggara jasa elektronik. Dua hal penting yang ditegaskan yaitu penyelenggara sistem elektronik wajib melakukan penghapusan dan menyediakan mekanisme penghapusan informasi elektronik dan/ atau dokumen elektronik yang tidak relevan atas dasar permintaan orang yang dirugikan berdasarkan penetapan pengadilan.

Satu sisi UU ITE Perubahan menekankan pada kewajiban untuk penghapusan informasi elektronik yang tidak relevan, sedangkan di sisi lain ditegaskan pentingnya mekanisme penghapusan. Artinya, UU ITE Perubahan memberikan penegasan akan kewajiban penghapusan informasi elektronik atas dasar 2 (dua) syarat utama, yaitu syarat materiil dan syarat formil yaitu mekanisme penghapusan informasi elektronik yang tidak relevan. Pertimbangan substansi yang dipersaratkan yaitu informasi elektronik/dokumen elektronik tidak relevan. Pemahaman atas frasa "tidak relevan" disini tidak dijelaskan dalam UU ITE Perubahan. Istilah "relevan" menurut $\mathrm{KBBI}^{44}$ diartikan sebagai "hubungan atau kaitan". Sehingga jika dipahami secara kontekstual dalam Pasal 26 ayat (3) UU ITE Perubahan menjadi informasi/dokumen elektronik

\footnotetext{
44 Tim Penyusun Kamus Pusat Bahasa, Op.cit., hlm. 1139.
} 
yang tidak ada hubungan atau kaitan menurut orang yang bersangkutan. Suatu informasi/dokumen elektronik dinilai tidak memiliki hubungan atau kaitan dapat dimungkinkan dalam arti merugikan bagi orang yang bersangkutan. Pemahaman terakhir ini penulis peroleh dengan menggunakan asas ejusdem generis ${ }^{45}$ yaitu memahami penggunaan suatu frasa dengan memahami sistematika ketentuan hukum terkait. Ketentuan hukum Pasal 26 ayat (3) UU ITE Perubahan tidak terpisahkan dari Pasal 26 ayat (1) UU ITE Perubahan. Prinsip utama dari penggunaan informasi di media elektronik yang menyangkut data pribadi seseorang harus disetujui orang yang bersangkutan. Oleh karena itu, dapat disimpulkan bahwa frasa "tidak relevan" Pasal 26 ayat (3) dimaksudkan dengan informasi yang dinilai merugikan orang yang bersangkutan dengan penyebarluasan informasi tersebut.

Mekanisme penerapan hak untuk dilupakan dengan demikian telah diatur dalam Pasal 26 UU ITE Perubahan mulai dari syarat substansi maupun syarat admnistrasi. Mekanisme tersebut dapat digambarkan dalam bagan sebagai berikut:

\section{Bagan 2.}

Mekanisme Penghapusan Informasi/Dokumen Elektronik Menurut Pasal 26 UU ITE Perubahan

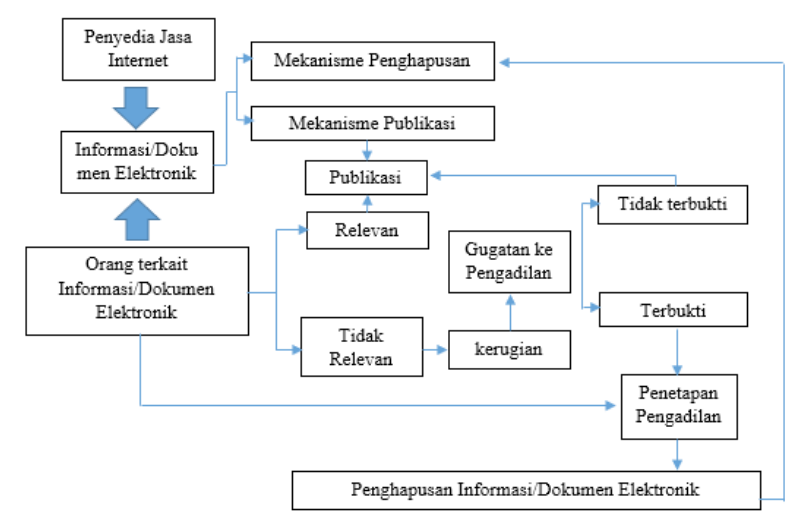

Sumber: Diolah oleh Penulis, 2019
Berdasarkan bagan tersebut, mekanisme penghapusan terkait erat dengan informasi/ dokumen elektronik menilai ada yang tidak relevan. Penilaian tersebut tidak serta merta mengharuskan penyedia jasa elektronik melakukan penghapusan informasi/dokumen elektronik terkait. Walaupun orang terkait melakukan permohonan atau permintaan secara mandiri, hal tersebut tidak mengikat penyedia jasa elektronik mengabulkan permintaan. Orang terkait harus melakukan gugatan atas informasi/dokumen elektronik yang tidak relevan dengan dasar keberatan adanya adanya kerugian yang ditimbulkan. Jika melihat bentuk upaya hukum yang diatur dalam Pasal 26 UU ITE Perubahan, upaya hukum dalam hal keperdataan yang diatur sedangkan upaya hukum dalam perkara pidana tidak mendapat pengaturan khusus. Hal tersebut tidak berarti jika ada perkara pidana terkait penggunaan atau penyalahgunaan informasi/ dokumen elektronik yang merugikan ketertiban umum atau kepentingan seseorang (korban) tidak dapat diajukan permohonan penghapusan informasi/dokumen elektronik.

Penghapusan informasi/dokumen elektronik dapat dilakukan setelah terbukti perbuatan yang didakwakan. Lebih lanjut proses pembuktian di pengadilan atas pengajuan kerugian dibuktikan ketika hal yang diajukan keberatan oleh seseorang atau korban terbukti, maka saat itu juga dimintakan penetapan pengadilan untuk dapat dilakukan penghapusan data kepada penyedia jasa informasi. Tentunya pengadilan pun memiliki kewenangan untuk memberikan penilaian berdasarkan hukum dan keadilan demi menghadirkan keadilan substantif. ${ }^{46}$ Penetapan pengadilan tersebut menjadi dasar hukum yang kuat agar penyedia jasa informasi melakukan penghapusan data pada yang berada di bawah kendalinya. Hal ini berarti penyedia jasa informasi wajib melakukan penghapusan pada search engine atas informasi/dokumen elektronik

\footnotetext{
45 Ian McLeod, et al., 1996, Legal Method, Palgrave Macmillan, Hampshire, hlm. 281-294.

46 Mohammad Jamin, "Reinforcing the Status of Customary Law as a Basis for Adjidicating in the Judicial Power System in Indonesia", International Journal of Advanced Science and Technology, Vol. 29, No. 03, 2020, hlm. 5105.
} 
yang dimintakan. Penghapusan informasi/dokumen Eeektronik yang tidak relevan jika dipahami dari bentuk pidana yang dijatuhkan merupakan bentuk tindakan yang diberikan oleh hakim untuk melindungi kepentingan korban. Sebagai sebuah tindakan maka hakim tetap memerhatikan tuntutan dari penuntut umum atas informasi/dokumen elektronik yang tidak relevan. Begitu pula dengan penetapan penghapusan informasi/dokumen elektronik pada perkara perdata yang harus menjadi satu bagian dari gugatan penggugat atas informasi/ dokumen elektronik yang dianggap tidak relevan.

\section{Kesimpulan}

Berdasarakan hasil penelitian dapat disimpulkan bahwa pertama, hak untuk dilupakan telah dimuat dalam Pasal 26 UU ITE secara komprehensif dari sisi substansi dan perolehannya. Pemaknaan hak untuk dilupakan mengalami perkembangan sebagai bagian dari hak asasi manusia yang diakui Undang-Undang Dasar Negara Republik Indonesia Tahun 1945 sebagai pemenuhan kebutuhan akan eksistensi diri menyangkut perlindungan hak privasi diri. Penjelasan Pasal 26 ayat (1) UU ITE mengenalkan hak untuk dilupakan sebagai bagian dari hak privasi atau hak pribadi dengan penekanan perlindungan kepentingan diri dari publikasi informasi/dokumen elektronik yang merugikan dirinya. Artinya jika dipahami hak pribadi dalam Penjelasan Pasal 26 UU UTE Perubahan masih termasuk dalam ruang lingkup hak privasi sebagaimana ditegaskan dalam ECHR yang mengenal dua bentuk, right of pubicity dan privacy right. Pengaturan hak pribadi dalam UU ITE Perubahan menunjukkan perhatian atas jaminan hak pribadi, yaitu right to publicity.

Kedua, hak privasi masih belum diatur dengan jelas dalam UU ITE Perubahan sehingga jaminan perlindungan korban tidak jelas terutama mekanisme pemenuhan haknya. Perlindungan korban pun masih terbatas pada adanya informasi/ dokumen elektronik yang tidak relevan berdasar adanya kerugian korban. Pemahaman seseorang sebagai korban dalam UU ITE dengan demikian masih terbatas pada ruang lingkup keperdataan bukan pidana. Mekanisme penanganan korban atas hak untuk dilupakan pun sangat jelas menunjukkan pemenuhan kerugian yang dialami korban. Ketiadaan mekanisme pemenuhan hak untuk dilupakan dalam perkara pidana pun harus mengikuti mekanisme pemenuhan hak untuk dilupakan dalam perkara perdata.

\section{DAFTAR PUSTAKA}

\section{A. Buku}

Darell, Keith B., 2009, Issues in Internet Law: Society, Technology and the Law, Fifth Edition, Amber Book, Washington.

Edwards L, et al., 2000, Law and the Internet: A Framework for Electronic Commerce, Second Edition, Hart Publishing, Oxford. Galaway, IBurt, et al., 1981, Perspectives on Crime Victims, Mosby, St. Loius.

Lim, Yee Fen., 2007, Cyberspace Law: Commentaries and Materials, Second edition, Oxford University Press, New York.

Machmud Marzuki, Peter., 2008, Pengantar Ilmu
Hukum, Kencana Prenada Media Group, Cetakan kedua, Jakarta. 2016, Penelitian Hukum, Kencana Prenada Media Group, Jakarta.

Newburn, T., 2007, Criminology, Willan Publishing, Portland.

Susilo, Ignatius Bagus., et al., 2003, Kompilasi Instrumen Internasional Hak Asasi Manusia Berikut Ratifikasinya dalam Peraturan Perundang-Undangan di Indonesia, Pusat Studi Hak Asasi Manusia Universitas Surabaya, Surabaya.

Tim Penyusun Kamus Pusat Bahasa, 2008, Kamus

Bahasa Indonesia Pusat Bahasa, Gramedia 
Pustaka Utama, Jakarta.

Wacks, Raymond., 2013, Privacy and Media Freedom, Croydon, Oxford.

\section{B. Artikel Jurnal}

Adebayo, Haleemah Bukola, et al., "Trajectories of University of Ibadan Undergraduates' Exposure to Cyber Pornography", Journal of Social, Behavioral and Health Sciences, Vol. 12, Issue 1, 2018.

Aswari, Aan, et al., "Harmonisasi Hukum Hak untuk Dilupakan bagi Korban Digital terhadap Calon Mahasiswa di Makassar", Kanun Jurnal Ilmu Hukum, Vol. 20, No. 1, April 2018.

Brown, Jonathan, 'Revenge porn' and the actio iniuriarum: using 'old law' to solve 'new problems”, Legal Studies, Vol. 38, 2018.

Christianto, Hwian, "Revenge porn sebagai Kejahatan Kesusilaan Khusus: Perspektif Sobural", Jurnal Veritas et Justitia, Vol. 3, No. 2, Desember 2017.

DeKeseredy, Walter S, "Critical Criminological Understandings of Adult Pornography and Woman Abuse: New Progressive Directions in Research and Theory", International Journal for Crime, Justice and Social Democracy, Vol. 4, No. 4, 2015.

Fattah, Ezzat Abdel, "Towards A Criminological Classification of Victims", Criminology and Police Science Journal, Vol. 58, No. 4, Desember 1967.

Fay, Meghan, "The Naked Truth: Insufficient Coverage for Revenge Porn Victims at State Law and the Proposed Federal Legislation to Adequately Redress Them", Boston College Law Review, Vol. 59, No. 5, 2018.

Franklin, Zak, "Justice for Revenge Porn Victims: Legal Theories to Overcome Claims of Civil Immunity by Operators of Revenge Porn Websites", California Law Review, Vol. 102, 2014.

Hald, Gert Martin, et al., "What Types of Pornography Do People Use and Do They
Cluster? Assesing Types and Categories of Pornography Consumption in a Large-Scale Online Simple", Journal of Sex Research, Vol. 53, No. 7, 2016.

Jaishankar, K, "Sexting: A new form of victimless crime?", International Journal of Cyber Criminology, Vol. 3, Issue 1, Januari-Juni 2009.

Jamin, Mohammad, "Reinforcing the Status of Cutomary Law as a Basis for Adjidicating in the Judicial Power System in Indonesia", International Journal of Advanced Science and Technology, Vol. 29, No. 03, 2020.

Keilty, Patrick, "Embodied Engagements with online pornography", The Information Society, Vol. 32, No. 1, 2016.

Kirchengast, Tyrone, "The Limits of Criminal Law and Justuce: 'revenge porn' Criminalization, Hybird Responses and The Ideal Victim", UniSA Student Law Review, Vol. 2, No. 42, Desember 2016.

Kumar, Alok Prasanna, "Right to be Forgotten' in Indian Law", Economic and Political Review, Vol. 52, No. 11, Maret 2017.

Marsui, Shigenori, "The Criminalization of Revenge Porn in Japan", Washington International Law Journal Association, Vol. 24, No. 2, April 2015.

Ngo, Fawn T, et al., "Sexting: Current Research Gaps and Legislative Issue: General Editors' Introduction to the Special Issue", International Journal of Cyber Criminology, Vol. 11, Issue 2, Juli-Desember 2017.

Nugraha, Ridha Aditya, "Perlindungan Data Pribadi dan Privasi Penumpang Maskapai Penerbangan pada Era Big Data", Jurnal Mimbar Hukum, Vol. 30, No. 2, Juni 2018.

Perangin-angin, Ita Iya Pulina, et al., "Kewajiban dan Tanggung Jawab Negara Memberikan Perlindungan Hukum terhadap Perempuan Korban Revenge Porn di Indonesia", Diponegoro Law Journal, Vol. 8, No. 1, 2019.

Saulawa, Mu'azu Abdullahi, “Cyberpornography: 
an Analysis of the Legal Framework", Global Journal of Politics and Law Research, Vol. 3, No. 2, April 2015.

Sweeny, JoAnne, "Gendered Violence and VictimBlaming: The Law's Troubling Response to Cyber-Harassment and Revenge Pornography", International Journal of Technoethics, Vol.8, Issue 1, 2017.

\section{Makalah}

Mudzakkir, "Perkembangan Viktimologi dan Hukum Pidana", Makalah, Pelatihan Hukum Pidana dan Krimilogi Kerjasama Fakultas Hukum UGM dan Masyarakat Hukum Pidana dan Kriminologi Indonesia (MAHUPIKI), Yogyakarta, 23-27 Februari 2014.

\section{Internet}

Asosiasi Penyelenggara Jasa Internet Indonesia, "Info Grafis Hasil Survey 2017", www. teknoprenuer.com, diakses 10 April 2018.

Danielle Keats Citron, et al., "Criminalizing Revenge Porn", https://law.yale.edu/system/ files/area/center/isp/documents/danielle_ citron___criminalizing_ revenge_porn_fesc.pdf, diakses 12 September 2019.

\section{E. Peraturan Perundang-undangan}

Undang-Undang Nomor 13 Tahun 2006 tentang Perlindungan Saksi dan Korban (Lembaran Negara Republik Indonesia Tahun 2006 Nomor 64, Tambahan Lembaran Negara Republik Indonesia Nomor 4635)

Undang-Undang Nomor 11 Tahun 2008 tentang Informasi dan Transaksi Elektronik (Lembaran Negara Republik Indonesia Tahun 2008 Nomor 64, Tambahan Lembaran Negara Republik Indonesia Nomor 58, Tambahan Lembaran Negara Republik Indonesia Nomor 4843)

Undang-Undang Nomor 44 Tahun 2008 tentang Pornografi (Lembaran Negara Republik Indonesia Tahun 2008 Nomor 181, Tambahan Lembaran Negara Republik Indonesia Nomor 4928)

Undang-Undang Nomor 19 Tahun 2016 tentang Perubahan Undang-Undang Nomor 11 Tahun 2008 tentang Informasi dan Transaksi Elektronik (Lembaran Negara Republik Indonesia Tahun 2016 Nomor 251, Tambahan Lembaran Negara Republik Indonesia Nomor 58, Tambahan Lembaran Negara Republik Indonesia Nomor 5952) 